\title{
Serological survey of caprine arthritis-encephalitis virus infection in Japan
}

\author{
Misako KONISHI ${ }^{1) *}$, Yoko HAYAMA ${ }^{1)}$, Hiroaki SHIRAFUJI ${ }^{2}$, Ken-ichiro KAMEYAMA ${ }^{1)}$, Kenji MURAKAMI ${ }^{3)}$, \\ Toshiyuki TSUTSUI ${ }^{1)}$ and Hiroomi AKASHI ${ }^{4}$ \\ 1) National Institute of Animal Health, 3-1-5 Kannondai, Tsukuba, Ibaraki 305-0856, Japan \\ ${ }^{2)}$ National Institute of Animal Health (Kyushu Research Station), 2702 Chuzan, Kagoshima, Kagoshima 891-0105, Japan \\ ${ }^{3)}$ Iwate University, 3-18-8 Ueda, Morioka, Iwate 020-8550, Japan \\ 4)Emeritus Professor, The University of Tokyo, 1-1-1 Yayoi, Bunkyo, Tokyo 113-8657, Japan
}

(Received 24 June 2015/Accepted 13 October 2015/Published online in J-STAGE 24 October 2015)

ABSTRACT. A serological survey of caprine arthritis-encephalitis virus (CAEV) infection was conducted from September 2006 to February 2007 in Japan. A total of 857 serum samples were collected from 113 herds in 28 prefectures and were analyzed for the presence of CAEV antibodies using agar gel immunodiffusion test. The seroprevalence of CAEV infection at the herd and animal levels was $15.0 \%$ (17/113) and $10.0 \%(86 / 857)$, respectively. Large farms with more than 10 goats and with animals for dairy and breeding purposes had higher seroprevalence $(P<0.05)$. The results of this study provide useful information to consider effective control programs against CAEV infection in Japan.

KEY WORDS: caprine arthritis-encephalitis virus, epidemiological survey, seroprevalence

doi: 10.1292/jvms.15-0357; J. Vet. Med. Sci. 78(3): 447-450, 2016

Caprine arthritis-encephalitis virus (CAEV), an RNA virus belonging to the genus Lentivirus in the family Retroviridae, is the causative agent of CAE, which is characterized by progressive degenerative inflammatory lesions in multiple regions $[4,18]$. Infected animals develop antibodies against CAEV and shed the virus for life in colostrum $/ \mathrm{milk}$, blood and respiratory tract secretions [6].

CAEV and maedi-visna virus (MVV), which infect sheep, share a high sequence homology and genomic organization, and antigenic cross-reactions occur between the structural proteins of these viruses $[10,18]$. Thus, both CAEV and MVV are designated as small ruminant lentiviruses (SRLVs) [4, 16-18]. SRLVs have been identified in most countries that rear sheep and goats, including Japan $[12,14,16]$. Because SRLVs cause both direct and indirect economic losses owing to decreased productivity and delayed maturity, diagnostic methods and programs to control the transmission of SRLVs have been established in countries with large goat and sheep industries [16, 17]. Global surveys and epidemiological studies to identify the risk factors associated with SRLV infection have been conducted in the same countries $[1-3,5-9,13,15,19-22]$. These previous studies revealed that ingestion of infected colostrum/milk or direct contact with infected animals is the main risk factor for the transmission of SRLVs within a herd [4]. In addition, large herd size,

*Correspondence to: Konishi, M., Viral Disease and Epidemiology Research Division, National Institute of Animal Health, National Agriculture and Food Research Organization (NARO), 3-1-5 Kannondai, Tsukuba, Ibaraki 305-0856, Japan.

e-mail: mkonishi@affrc.go.jp

C2016 The Japanese Society of Veterinary Science

This is an open-access article distributed under the terms of the Creative Commons Attribution Non-Commercial No Derivatives (by-nc-nd) License $<$ http://creativecommons.org/licenses/by-nc-nd/4.0/>. increased age, high stocking density, prolonged duration of exposure to infected animals and extensive rearing systems have also been indicated as risk factors [4, 13, 16, 17].

In Japan, CAE was first detected in 2002 at one of the largest dairy goat farms in the country [12]. Because the infected farm was one of the largest suppliers of live goats to other farms throughout Japan, a nationwide survey of CAEV infection was required to elucidate the prevalence of CAE. However, the goat industry in Japan is not very large, with only approximately 19,000 goats throughout the country in 2014, according to the Japan Livestock Technology Association (Statistics of number of goats in each prefecture; http://jlta.lin.gr.jp/sheepandgoat/goat/toukei.html), and thus, information on goat herd operations is limited. In this study, a serological survey of goat herds was conducted to reveal the seroprevalence of CAEV among goat populations. In addition, information on herd management practices was collected to understand farming practices of goats in Japan.

A voluntary survey of goat herds was conducted in 28 Japanese prefectures from September 2006 to February 2007. Veterinary officers of each prefectural government visited herds and collected a total of 857 blood samples from 113 herds. The Animal Ethical Committee and the Animal Care and Use Committee of National Institute of Animal Health (NIAH) approved the sampling. Sera were separated at prefectural laboratories and sent to NIAH for antibody detection by the agar gel immunodiffusion (AGID) test, as previously described [12]. On the day of blood sampling, the owners of the herds were asked to answer a questionnaire prepared by the authors. The questionnaire was designed to get information regarding herds and individual animals. The questions regarding herds included the number of goats in the herd, the purpose of farming (breeding, dairy or other), grazing practices, introduction of goats from other herds, housing conditions, breeding and rearing methods, and feed- 
Table 1. Comparison of seroprevalence of CAEV at the herd level

\begin{tabular}{|c|c|c|c|c|}
\hline Variable & Categories & Number of herds & Positive herds (\%) & $P$ \\
\hline \multirow{2}{*}{$\begin{array}{l}\text { Number of goats } \\
\text { in herd }\end{array}$} & $<10$ & 54 & 9.3 & 0.016 \\
\hline & $\geq 10$ & 31 & 32.3 & \\
\hline \multirow{3}{*}{ Purpose of farming } & Breeding & 11 & 45.5 & $<0.001$ \\
\hline & Dairy & 11 & 45.5 & \\
\hline & Other & 63 & 7.9 & \\
\hline \multirow{2}{*}{ Grazing } & Yes & 31 & 29 & 0.073 \\
\hline & No & 54 & 11.1 & \\
\hline \multirow{2}{*}{$\begin{array}{l}\text { Presence of } \\
\text { purchased goats }\end{array}$} & Yes & 57 & 22.8 & 0.128 \\
\hline & No & 28 & 7.1 & \\
\hline \multirow{2}{*}{ Goats were reared } & Separately & 61 & 19.7 & 0.54 \\
\hline & Together & 24 & 12.5 & \\
\hline \multirow{3}{*}{ Breeding } & Natural mating & 73 & 20.5 & 0.224 \\
\hline & Artificial Insemination & 2 & 0 & \\
\hline & No breeding & 10 & 0 & \\
\hline \multirow{3}{*}{ Rearing } & Naturally & 74 & 20.3 & 0.258 \\
\hline & Artificially & 1 & 0 & \\
\hline & No breeding & 10 & 0 & \\
\hline \multirow{3}{*}{ Use of milk replacer } & Yes & 2 & 50 & 0.157 \\
\hline & No & 73 & 19.2 & \\
\hline & No breeding & 10 & 0 & \\
\hline \multirow{3}{*}{ Feeding pooled milk } & Yes & 3 & 33.3 & 0.245 \\
\hline & No & 72 & 19.4 & \\
\hline & No breeding & 10 & 0 & \\
\hline
\end{tabular}

ing of milk replacer or pooled milk. The questionnaire also included information regarding gender, age, breed, purpose/ use, origin (purchased or born to the herd), field grazing, parturition number (for female goats) and health status (including case histories) of the animals. Infection was defined as a seropositive animal identified by the AGID test, and herds were defined as infected if at least one goat in the herd was infected. Collected data were stored and analyzed using commercially available spreadsheet software (Excel 2007; Microsoft Corp., Redmond, WA, U.S.A.). Descriptive analysis was performed to examine features of goat farming and the prevalence of CAEV infection in Japan. Statistical analyses were performed using SPSS statistical software (IBM SPSS Statistics 19; IBM Japan, Tokyo, Japan).

Of 857 goats, 86 were seropositive, resulting in a seroprevalence of $10.0 \%$ at the animal level [95\% confidence interval (CI), 8.0-12.1\%], whereas 17 of 113 herds were found to be infected, resulting in a seroprevalence of $15.0 \%$ at the herd level $(95 \% \mathrm{CI}, 8.5-21.6 \%)$. No goat examined in this study exhibited clinical symptoms of CAE, such as pneumonia, arthritis or mastitis. Approximately $60 \%$ of the 107 herds that answered the total number of goats, consisted of fewer than 10 goats. Only three herds had more than 100 goats. The average herd consisted of 15 goats (range, 1-216). The primary reasons for rearing goats were dairy production $(37.9 \%)$, pets $(19.6 \%)$, experimental animals $(14.1 \%)$, breeding $(6.8 \%)$ and other uses $(21.6 \%)$. No farm reared goats for meat purposes. In most herds, goats were bred by natural mating, and kids were naturally reared with their dams. The use of milk replacer and pooled milk was very rare (2/113 herds). The following breeds of goat (635) were observed in this study: Saanen (428), Alpine (57), Nubian (7), Toggenburg (6), Angora (4), Shiba (85), Tokara (35) and Yakushima (13). The remaining goats were crossbreeds (114) or unknown breeds (108). The seroprevalence of Saanen, Alpine, Nubian and crossbreed goats in Japan was $14.3 \%$ (61/428), $24.6 \%$ (14/56), $14.3 \%$ (1/7) and $8.8 \%$ (10/114), respectively. Among the crossbreeds, all infected animals were crosses between Saanen and Alpine breeds. All other breeds (including those unknown) were seronegative based on the AGID test. The age of the examined goats ranged from 1 month to 12 years (average age, 2.6 years).

Excluding those data with missing values in one or more fields, data concerning 85 herds and 678 goats were used for statistical analyses. At the herd level, the seroprevalence of goats reared for breeding and dairy uses was significantly higher than that for other purposes $\left(P<0.01, \chi^{2}\right.$-test $)$ (Table 1). At the animal level, gender, age, breed, purpose/ use, acquisition (purchased or born to the herd) and grazing (yes or no) significantly influenced the seroprevalence $\left(P<0.05, \chi^{2}\right.$-test $)$ (Table 2).

This is the first epidemiological study of CAEV infection in Japan. Although participation in this study was voluntary, we believe that our results reasonably reflect current herd management practices and the prevalence of CAEV among the goat population in Japan, as prefectures with large numbers of goat herds were covered by this survey. In this study, overall seroprevalence at the animal level was $10 \%$, and that 
Table 2. Comparison of seroprevalence of CAEV at the animal level

\begin{tabular}{llccc}
\hline \multicolumn{1}{c}{ Variables } & \multicolumn{1}{c}{ Categories } & Number of goats & Positive goats (\%) & $P$ \\
\hline \multirow{2}{*}{ Gender } & Female & 485 & 11.3 & 0.014 \\
& Male & 193 & 5.2 & \\
\hline \multirow{3}{*}{ Age (years) } & $<1$ & 208 & 5.3 & 0.001 \\
& $1-2$ & 192 & 6.8 & \\
\hline \multirow{2}{*}{ Breed } & $\geq 3$ & 278 & 14.7 & \\
& Saanen & 369 & 11.7 & 0.046 \\
& Others & 309 & 7.1 & \\
\multirow{2}{*}{ Purpose/use } & Breeding & 53 & 22.6 & $<0.001$ \\
& Dairy & 278 & 15.1 & \\
\hline \multirow{2}{*}{ Acquisition } & Others & 347 & 3.2 & \\
\hline \multirow{2}{*}{ Grazing } & Purchased & 162 & 16 & 0.001 \\
& Born on the herd & 516 & 7.6 & \\
\hline \multirow{2}{*}{ Number of goats } & Yes & 339 & 6.2 & 0.003 \\
in herd & No & 339 & 13 & \\
\hline
\end{tabular}

at the herd level was $15 \%$. Previous studies indicated that countries with large-scale goat farms and intensive dairy farming generally had a high seroprevalence of CAEV $(>65.0 \%$ at the animal level), whereas those with smallscale farms had a low seroprevalence (approximately $10 \%$ at the animal level) $[2,6]$. Considering that most goat herds in Japan are small, our results conform to these studies. In addition, herds with more than 10 goats appeared to have a higher seroprevalence of CAEV than smaller herds. These results also indicate that herd size influences seroprevalence of CAEV in goat herds.

Our results revealed that goats were mainly reared for personal use, with large-scale commercial farms being relatively rare in Japan. Our results also showed that farms keeping goats for breeding and dairy purposes had higher seroprevalence than those for other purposes. This finding appears reasonable, because CAE primarily occurs in dairy herds [17], and these farms often introduce goats from other herds for the genetic improvement of animals. The spread of SRLVs via live animal trade has been confirmed epidemiologically and phylogenetically. This practice was accordingly identified as a major risk factor for the spread of SRLVs between herds in previous studies $[4,16]$. The frequent movement of animals among breeding and dairy farms might increase the risk of introduction of infected goats and cause higher seroprevalence in those farms.

Our results showed that local Japanese breeds (Shiba, Tokara and Yakushima) are rarely reared with goats acquired from abroad, and instead, they are usually reared on small-scale farms as pets or experimental animals (data not shown). In contrast to "non-native" breeds, goats of local Japanese breeds are rarely transferred to other herds, and all goats of local Japanese breeds in this study were seronegative for CAEV. Although further studies, including molecular epidemiological studies of viral genes, are required, our findings suggest that the spread of CAEV throughout Japan may occur via trading infected goats.

Several studies have reported a correlation between the breed of goat and risk of CAEV [9, 19, 20]. In the present survey, Saanen was the most common breed and was reared for many purposes, including breeding, dairy and experimental uses or as pets, throughout Japan. The results of the statistical analysis showed that seroprevalence in Saanen was significantly higher than that in other breeds. However, caution should be exercised as Alpine and Nubian breeds were also found to have a high seroprevalence and all were reared with Saanen goats in the same herd. Considering both the high seroprevalence of these dairy goats and absence of seropositive goats in the Japanese local breeds, the risk for CAEV infection may be related to herd management, and not the type of breed.

The results of the present study provide useful information on the seroprevalence of CAEV and herd management practices of goats in Japan. Considering the seroprevalence observed in this study, disease management should be prioritized by large-scale dairy farms, because of the frequent on/ off movements of animals at such goat farms. Control measures may include use of milk-deprived rearing, periodical testing and isolation of infected animals [11]. Implementation of control measures targeting highly affected herds will contribute to the eradication of CAEV in Japan.

ACKNOWLEDGMENTS. The authors wish to thank the employees of the Livestock Hygiene Service Center and the goat owners who participated in this study for their cooperation in providing blood samples and sharing information. This study was partly supported by a special grant from the Ministry of Agriculture, Forestry and Fisheries of Japan.

\section{REFERENCES}

1. Adair, B. M. 1986. Serological surveillance for maedi-visna 
virus and caprine arthritis-encephalitis virus in Northern Ireland. Vet. Rec. 118: 422-423. [Medline] [CrossRef]

2. Adams, D. S., Oliver, R. E., Ameghino, E., DeMartini, J. C., Verwoerd, D. W., Houwers, D. J., Waghela, S., Gorham, J. R., Hyllseth, B. and Dawson, M. 1984. Global survey of serological evidence of caprine arthritis-encephalitis virus infection. Vet. Rec. 115: 493-495. [Medline] [CrossRef]

3. Bandeira, D. A., de Castro, R., Azevedo, E., Melo, L. and de Melo, C. 2009. Seroprevalence of caprine arthritis-encephalitis virus in goats in the Cariri region, Paraiba state, Brazil. Vet. J. 180: 399-401. [Medline] [CrossRef]

4. Blacklaws, B. A., Berriatua, E., Torsteinsdottir, S., Watt, N., de Andres, D., Klein, D. and Harkiss, G. 2004. Transmission of small ruminant lentiviruses. Vet. Microbiol. 101: 199-208. [Medline] [CrossRef]

5. Brülisauer, F., Vogt, H., Perler, L. and Rüfenacht, J. 2005. Risk factors for the infection of Swiss goat herds with small ruminant lentivirus: a case-control study. Vet. Rec. 157: 229-233. [Medline] [CrossRef]

6. Contreras, A., Corrales, J. C., Sánchez, A., Adúriz, J. J., González, L. and Marco, J. 1998. Caprine arthritis-encephalitis in an indigenous Spanish breed of dairy goat. Vet. Rec. 142: 140-142. [Medline] [CrossRef]

7. Dawson, M. and Wilesmith, J. W. 1985. Serological survey of lentivirus (maedi-visna/caprine arthritis-encephalitis) infection in British goat herds. Vet. Rec. 117: 86-89. [Medline] [CrossRef]

8. Ghanem, Y., El-Khodery, S., Saad, A., Elragaby, S., Abdelkader, A. and Heybe, A. 2009. Prevalence and risk factors of caprine arthritis encephalitis virus infection (CAEV) in Northern Somalia. Small Rumin. Res. 85: 142-148. [CrossRef]

9. Gufler, H., Gasteiner, J., Lombardo, D., Stifter, E., Krassnig, R. and Baumgartner, W. 2007. Serological study of small ruminant lentivirus in goats in Italy. Small Rumin. Res. 73: 169-173. [CrossRef]

10. Hötzel, I. and Cheevers, W. 2003. Caprine arthritis-encephalitis virus envelope surface glycoprotein regions interacting with the transmembrane glycoprotein: structural and functional parallels with human immunodeficiency virus type 1 gp120. J. Virol. 77: 11578-11587. [Medline] [CrossRef]

11. Konishi, M., Nagura, Y., Takei, N., Fujita, M., Hayashi, K., Tsukioka, M., Yamamoto, T., Kameyama, K. and Murakami, K. 2011. Combined eradication strategy for CAE in a dairy goat farm in Japan. Small Rumin. Res. 99: 65-71. [CrossRef]

12. Konishi, M., Tsuduku, S., Haritani, M., Murakami, K., Tsuboi, T., Kobayashi, C., Yoshikawa, K., Kimura, K. M. and Sentsui, H. 2004. An epidemic of caprine arthritis encephalitis in Japan: isolation of the virus. J. Vet. Med. Sci. 66: 911-917. [Medline]
[CrossRef]

13. Leginagoikoa, I., Juste, R., Barandika, J., Amorena, B., De Andrés, D., Luján, L., Badiola, J. and Berriatua, E. 2006. Extensive rearing hinders Maedi-Visna Virus (MVV) infection in sheep. Vet. Res. 37: 767-778. [Medline] [CrossRef]

14. Oguma, K., Tanaka, C., Harasawa, R., Kimura, A., Sasaki, J., Goryo, M. and Sentsui, H. 2014. Isolation of maedi/visna virus from a sheep in Japan. J. Vet. Med. Sci. 76: 211-218. [Medline] [CrossRef]

15. Pérez, M., Biescas, E., de Andres, X., Leginagoikoa, I., Salazar, E., Berriatua, E., Reina, R., Bolea, R., de Andres, D., Juste, R., Cancer, J., Gracia, J., Amorena, B., Badiola, J. and Lujan, L. 2010. Visna/maedi virus serology in sheep Survey, risk factors and implementation of a successful control programme in Aragon (Spain). Vet. J. 186: 221-225. [Medline] [CrossRef]

16. Peterhans, E., Greenland, T., Badiola, J., Harkiss, G., Bertoni, G., Amorena, B., Eliaszewicz, M., Juste, R., Krassnig, R., Lafont, J., Lenihan, P., Pétursson, G., Pritchard, G., Thorley, J., Vitu, C., Mornex, J. and Pépin, M. 2004. Routes of transmission and consequences of small ruminant lentiviruses (SRLVs) infection and eradication schemes. Vet. Res. 35: 257-274. [Medline] [CrossRef]

17. Reina, R., Berriatua, E., Luján, L., Juste, R., Sánchez, A., de Andrés, D. and Amorena, B. 2009. Prevention strategies against small ruminant lentiviruses: an update. Vet. J. 182: 31-37. [Medline] [CrossRef]

18. Rosati, S., Mannelli, A., Merlo, T. and Ponti, N. 1999. Characterization of the immunodominant cross-reacting epitope of visna maedi virus and caprine arthritis-encephalitis virus capsid antigen. Virus Res. 61: 177-183. [Medline] [CrossRef]

19. Rowe, J. D., East, N., Franti, C., Thurmond, M., Pedersen, N. and Theilen, G. 1992. Risk factors associated with the incidence of seroconversion to caprine arthritis-encephalitis virus in goats on California dairies. Am. J. Vet. Res. 53: 2396-2403. [Medline]

20. Rowe, J. D., East, N., Thurmond, M., Franti, C. and Pedersen, N. 1992. Cohort study of natural transmission and two methods for control of caprine arthritis-encephalitis virus infection in goats on a California dairy. Am. J. Vet. Res. 53: 2386-2395. [Medline]

21. Shuaib, M., Green, C., Rashid, M., Duizer, G. and Whiting, T. L. 2010. Herd risk factors associated with sero-prevalence of Maedi-Visna in the Manitoba sheep population. Can. Vet. J. 51: 385-390. [Medline]

22. Torres-Acosta, J., Gutierrez-Ruiz, E., Butler, V., Schmidt, A., Evans, J., Babington, J., Bearman, K., Fordham, T., Brownlie, T., Schroer, S., Camara, E. and Lightsey, J. 2003. Serological survey of caprine arthritis-encephalitis virus in 83 goat herds of Yucatan, Mexico. Small Rumin. Res. 49: 207-211. [CrossRef] 